\title{
Erythema Discromicum Perstans Related with Oral Contraceptive and Progesterone Injections
}

\author{
Oral Kontraseptif ve Progesteron Enjeksiyonlarıla İlişkili Eritema Diskromikum Perstans
}

Gonca Soyuduru, Esra Adışen, Mehmet Ali Gürer

Gazi University Faculty of Medicine, Department of Dermatology, Ankara, Turkey

\begin{abstract}
Erythema discromicum perstans is clinically characterized by asymptomatic, hyperpigmented macules of various size on the face, trunk and extremities. It typically occurs in the second decade of life and generally affects those with phototype IV skin. The etiology of erythema discromicum perstans is unknown but associations with endocrinopathies, infestations, infections, and drug allergies have been reported. The association with oral contraceptives and progesterone injections has not been reported yet in the literature. Herein, we report a case of a 34 year old woman who presented with extensive and progressive erythema discromicum perstans induced and/or exacerbated by the ingestion of oral contraceptives and multiple progesterone injections. We aim to emphasize the "probable" side effect of these drugs. Awareness of this probable association deserves attention due to the widespread use of oral contraceptive pills and/or progesterone injections.
\end{abstract}

Key Words: Erythema discromicum perstans, oral contraceptives, progesterone

\section{ÖZET}

Eritema diskromikum perstans klinik olarak yüz, gövde ve ekstremitelerde yerleşen asemptomatik, değişik büyüklükte hiperpigmente maküllerle karakterizedir. Tipik olarak hayatın ikinci dekatında başlar ve deri fototipi IV olanları etkiler. Hastalığın etyolojisi bilinmemekle birlikte endokrinopatiler, enfestasyonlar, ilaç allerjileri ile birliktelikler bildirilmiştir. Oral kontraseptif ve progesteron enjeksiyonlarıyla ilişki ise daha önce tanımlanmamışırır. Bu yayında 34 yaşında oral kontraseptif ve progesterone enjeksiyonları kullanımıyla gelişen veya tetiklenen, yaygın ve ilerleyici eritema diskromikum perstans olgusu sunulmakta ve bu ilaçların olası etkilerine vurgu yapmak istenmektedir. Bu olası ilişki ve farkındalığı, oral kontraseptif ve progesteron enjeksiyonlarının yaygın olarak kullanılması nedeniyle ilgiyi haketmektedir.

Anahtar Sözcükler: Eritema diskromikum perstans, oral kontraseptifler, progesterone

Geliş Tarihi: 10.09 .2015

Kabul Tarihi: 03.11.2015

\section{INTRODUCTION}

Erythema discromicum perstans (EDP) first described by Ramirez in 1957 is a rare, benign and chronic disorder included in the group of acquired idiopathic hypermelanoses (1). It typically occurs in the second decade of life and generally affects those with skin phototype IV (2-8). The etiology of EDP is unknown but associations with endocrinopathies, infestations, infections, and drug allergies have been reported (2-9). The association with oral contraceptives and progesterone injections has not been reported yet in the literature. Herein, we report a case of 34 year old woman who presented with extensive and progressive EDP induced and/or exacerbated by ingestion of oral contraceptives and multiple progesterone injections.

\section{CASE REPORT}

A 34-year-old female patient presented to our clinic with progressive cutaneous pigmentary changes. Four years earlier, patient had noticed hyperpigmented lesions over the face after using of oral contraceptive pills due to ovarian cysts. Because of these lesions, the patient discontinued oral contraceptive pills and a progesteron injection was made. At that time, the lesions began to spread over the neck area. After cessation of all treatments, the lesions remained stable for two years. Two years ago the patient became pregnant and because of the abortion risk progesteron injections were again made three times at a week's interval. 
After these injections, these asymptomatic hyperpigmented areas progressively spread to trunk and extremities. The patient had no personal or familial history of photosensitivity or inflammatory skin disorders, or any systemic diseases. brown-gray-blue, oval to circular, discrete and coalescing patches with erythematous borders on the face, neck, trunk and upper extremities (Figure 1).
Dermatological examination revealed extensive, symmetric, hyperpigmented There was no mucosal involvement. Histopathological findings were consistent with a diagnosis of a late stage EDP. Sex hormones, thyroid function tests were within normal ranges. She was started on dapsone (200mg/day) after the confirmation of normal glucose-6-phosphate dehydrogenase (G6PD) activity level.
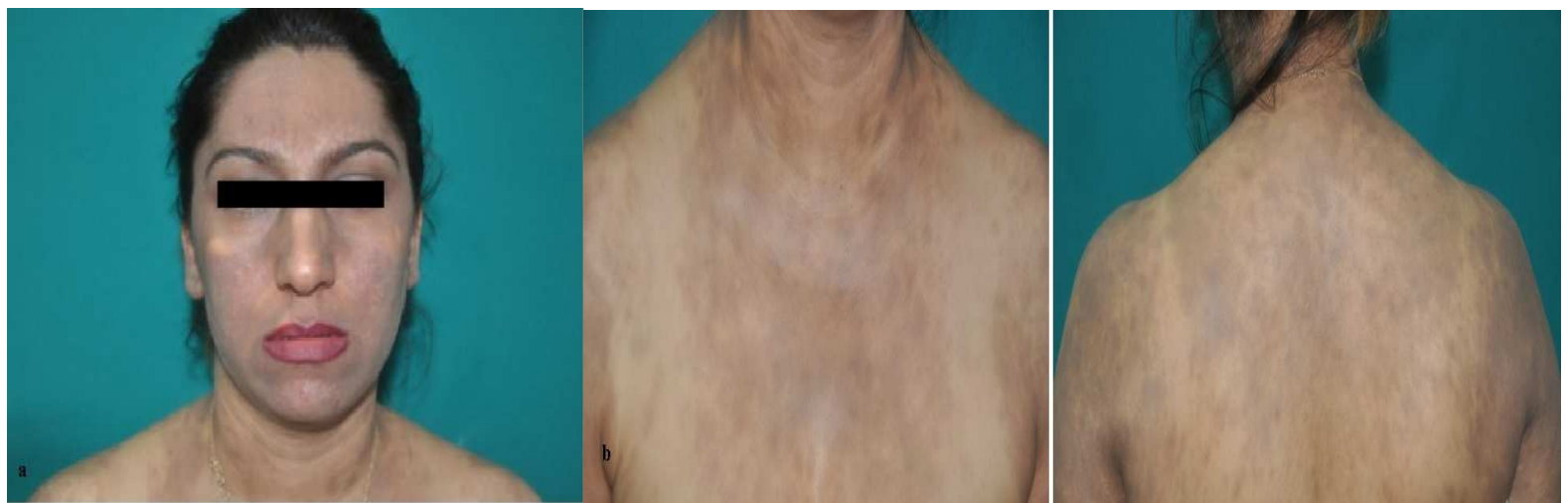

Figure 1. Extensive, symmetric, hyperpigmented, brown-gray-blue, oval to circular, discrete and coalescing patches with erythematous borders (a) on the face (b) neck, trunk, back and upper extremities.

\section{DISCUSSION}

EDP is characterized by blue-gray macules with raised, erythematous borders, most commonly located on the face, neck trunk and upper limbs, sparing mucosae, hands, feet and scalp (2-6). The lesions vary in size from $3 \mathrm{~mm}$ to very confluent patches and the individual lesions can be oval, irregular or even polycyclic in shape with slow centrifugal growth $(1,2-5)$. In the late stages, the patches turn gray-blue with ill-defined borders (6). In contrast to pediatric EDP in which spontaneous resolution may occur within a few years after the start of the disease, adult EDP tends to run a more persistent disease course $(2,4)$.

Many questions remain about EDP, especially regarding its etiology, pathogenesis and treatment. Neither the exact etiology nor the pathogenesis of the disease is known yet (2-5). Whether the disease results from an abnormality in cell-mediated immunity or is the result of a genetic susceptibility that causes predisposition to EDP remains a source of debate (2-7). The diagnosis is based on a combination of clinical and histological findings (1). In fact, the biopsy evaluation is primarily used to rule out other diagnoses including drug eruptions, lichen planus as to confirm that of EDP $(1,2)$.. Similar to that seen in our patient, the histological findings include mild basal cell layer vacuolar degeneration overlying an upper dermis with a mild perivascular mononuclear cell infiltrate and increased melanophage $(1,2,4,7)$. EDP may be viewed as originating at an early stage as an inflammatory reaction to an ingested agent or contactant or a chemical, followed by a progressive persistent hyperpigmentation (1). In the literature, EDP has been linked with a number of conditions including endocrinopathies, nematode infestations, pesticide exposure, human immunodeficiency virus and chronic hepatitis C infections, ammonium nitrate consumption, cobalt allergy, radiological contrast material, and medications such as oral antibiotics, benzodiazepine, omeprazole (1-9). The association with oral contraceptive pills and progesterone injections has not been reported yet in the literature. The Naranjo Adverse Drug Reactions (ADR) Probability Scale is a simple and widely used nonspecific scale, which classifies the probability that an adverse event is related to drug therapy (10). In our case, Naranjo ADR Reaction probability scale score was 6 and indicated that EDP in our patient was "probably" related with the progesterone injections. Drugs can cause hyperproduction of melanin by stimulating melanocytes; effecting the melanin clearance from dermal macrophages, accumulation of the drug in the dermis, influencing the synthesis of special pigments, the deposition of iron from drug-induced damage to dermal vasculate (9). Awareness of this probable association deserves attention due to the widespread use of oral contraceptive pills and/or progesterone injections.

\section{Conflict of interest}

No conflict of interest was declared by the authors

\section{REFERENCES}

1. Schwartz RA. Erythema dyschromicum perstans: the continuing enigma of Cinderella or ashy dermatosis. Int J Dermatol 2004; 43: 230-2.

2. Goihman-Yahr M. Letter: Erythema dyschromicum perstans revisited. Dermatol Online J 2011; 17: 14.

3. Vásquez-Ochoa LA, Isaza-Guzmán DM, Orozco-Mora B, Restrepo-Molina $R$, Trujillo-Perez J, Tapia FJ. Immunopathologic study of erythema dyschromicum perstans (ashy dermatosis). Int J Dermatol 2006; 45: 93741.

4. Torrelo A, Zaballos P, Colmenero I, Mediero IG, de Prada I, Zambrano A. Erythema dyschromicum perstans in children: a report of 14 cases. J Eur Acad Dermatol Venereol 2005; 19: 422-6.

5. Persechino S, Caperchi C, Cortesi G, Persechino F, Raffa S, Pulcini F, Tammaro A, Torrisi MR. Erythema dyschromicum perstans in phototype II women: three unusual clinical cases studied with electron microscopy. Eur J Dermatol 2011; 21: 261-2.

6. Bahadir S, Cobanoglu U, Cimsit G, Yayli S, Alpay K. Erythema dyschromicum perstans: response to dapsone therapy. Int J Dermatol 2004; 43: 220-2.

7. Baranda L, Torres-Alvarez B, Cortes-Franco R, Moncada B, Portales-Perez DP, Gonzalez-Amaro R. Involvement of cell adhesion and activation molecules in the pathogenesis of erythema dyschromicum perstans (ashy dermatitis). The effect of clofazimine therapy. Arch Dermatol 1997; 133: 325-9.

8. Penagos H, Jimenez V, Fallas V, O'Malley M, Maibach HI. Chlorothalonil, a possible cause of erythema dyschromicum perstans (ashy dermatitis). Contact Dermatitis 1996; 35: 214-8.

9. Chua S, Fung MC, Lee HY. Ashy dermatosis (erythema dyschromicum perstans) induced by omeprazole: a report of three cases. Int J Dermatol 2015 Jul 3. doi: 10.1111/ijd.12844.

10. Naranjo CA, Busto U, Sellers EM, Sandor P, Ruiz I, Roberts EA, Janecek E, Domecq C, Greenblatt DJ. A method for estimating the probability of adverse drug reactions. Clin Pharmacol Ther 1981; 30: 239-45. 